\title{
KIDNAPPED: \\ The Ethics of Paying Ransoms
}

\author{
Jeffrey W. Howard
}

\begin{abstract}
Should governments pay ransoms to terrorist organizations that unjustly kidnap their citizens? The United Kingdom and the United States refuse to negotiate with terrorist groups that kidnap and threaten to kill their people. In contrast, continental European countries, such as France and Germany, have regularly paid ransoms to rescue hostages. Who is right? This debate has raged in the public domain in recent years, but no sustained attempt has been made to subject the matter to philosophical scrutiny. This article explores this issue, focusing on the case of ransom payments to terrorist organizations. It contends that the state's duty to protect its citizens from murder grounds a defeasible obligation to pay ransoms. It considers the objection that a policy of paying ransoms endangers citizens abroad by increasing the likelihood of future kidnappings, and it explains why this objection is not sufficiently weighty. It then identifies a more powerful objection: namely, that a state's payment of ransoms makes the state complicit in the serious injustices that its ransom payments fund. It concludes that unless states can offset their contributions to such injustices, paying ransoms is wrong.
\end{abstract}

Kidnapping and then threatening to kill a person unless a ransom is paid is undeniably prima facie wrong. Even if there are conditions in which it could be justified, ${ }^{\mathrm{i}}$ no one should doubt that such conditions are both rare and lamentable. The most pressing moral question with respect to kidnapping involves not its permissibility but rather the moral requirements, permissions, and prohibitions that attach to possible responses to it.

The question of what to do in response to hostage-taking is a practical quandary in the contemporary foreign policy of liberal democracies. Al-Qaeda in the Islamic Maghreb has bankrolled a non-trivial portion of its terrorist 
operations in North Africa by kidnapping Europeans and then extracting ransoms from their families and governments. France alone has paid tens of millions of dollars to them and their affiliates since 2008. ${ }^{\text {ii }}$ The U.S. and U.K. governments, in contrast, standardly refuse to pay kidnappers. Most recently, the so-called Islamic State of Iraq and Syria (ISIS) has executed numerous hostages for whom ransoms were not paid, while releasing hostages whose polities acquiesced.

Who is right? Despite a fraught public debate about the right policy on ransoms, there has not been any proper investigation into this question by the philosophical community. The question of whether to pay ransoms to those who kidnap our co-citizens abroad raises deep and difficult questions of political theory: about the scope of the state's obligation to protect its members from harm, and about how to weigh the interests of one's co-citizens with the interests of foreigners whose lives are endangered by the organizations that ransom payments fund. It also raises deep and difficult questions of moral philosophy, namely, concerning the permissibility of aggregation under conditions of risk. No wonder, then, that normative theorists have shied away from this debate, a "perfect storm" of thorny controversies.

Now that Western journalists and aid workers have essentially fled ISISrun territory, the question of whether to pay ransoms is no longer as urgent to the democratic world as it was just two years ago. Yet we are entering a new period of instability. The time will come when kidnapping journalists and aid workers will once again be used as a tool of profiteering and terror. Insofar as the wealthy states of the world have a moral obligation to undertake 
development work in poorer countries, exposure to the risks of kidnapping may simply be unavoidable. It is thus imperative that philosophers weigh in on what the right policy in this area is.

This article aims to jumpstart that conversation, focusing specifically on the ethics of paying ransoms to unjust terrorist organizations. The view I ultimately defend involves three claims. First, I argue that the case against paying ransoms cannot simply be that it incentivizes greater hostage-taking, and so subjects certain agents to a greater risk of kidnapping in the future than they would otherwise face. Such agents - be they journalists or aid workers who face an increased risk of kidnapping under a policy of paying ransoms-are not the ones who have the weightiest complaint against such a policy. Second, I argue that the wrongness of paying ransoms traces to the fact that, by paying the ransoms, one makes a causal contribution to injustice. It is the victims of such injustice-the families in the towns that ISIS burns, its soldiers paid with Western cash-who hold a potentially decisive complaint against the policy of paying ransoms. Third, I argue that such a complaint is only potentially decisive since those who pay ransoms may be able to mitigate the pernicious consequences of doing so.

The argument proceeds in two phases. In the first phase (Parts II and III), I consider whether governments ought to pay ransoms, focusing strictly on the interests of currently or prospectively kidnapped persons. Part II develops the case for paying ransoms, while Part III poses an objection to the simple case-the incentives objection-and explains why, under certain plausible assumptions, this objection fails. Then I turn to the second phase of the 
argument (Parts IV and V), which widens the scope to include the interests of other people. Part IV poses a different objection to the case for paying ransoms-the complicity objection-and I argue that this objection succeeds under certain factual conditions, but not under others. Finally, Part V explores some related questions before concluding.

Because one's view on this issue depends on a range of prior commitments in political and moral theory, as I have already intimated, there is no way to defend a philosophically uncontroversial position. Those who reject the assumptions I make throughout can nevertheless benefit from the analysis I offer here, which will help them reason their way to their own conclusions.

\section{II}

Non-consequentialists must confront the possibility that even if paying ransoms results in worse outcomes, it is the right thing to do. "The Obligation of Subjects to the Sovereign," writes Thomas Hobbes, "is understood to last as long, and no longer, than the power lasteth by which he is able to protect them."iii Since Leviathan, political theorists have broadly agreed that a principal objective, if not raison d'etre, of political authority is to protect its subjects from the prospect of violent death. A fundamental moral aim of modern government, even if not the only aim, is to protect its citizens from murder.

To say that legitimate political authority has a duty to protect its citizens from murder does not entail that only its citizens have claims against such a state to be protected in this way. Even if all moral agents have positive duties to protect one another from the prospect of murder, a government's duty to 
protect its own citizens from murder is especially weighty. This is not because its citizens' lives have superior worth to the lives of non-citizens; no plausible view will dispute a modest cosmopolitan commitment to moral equality. Rather, it is because government rightly takes itself to have the particular responsibility for protecting the subset of agents that constitutes its citizenry. This responsibility can be justified in different ways, depending on one's political theory. ${ }^{\text {iv }}$ But one corollary is clear: citizens of a state have the right to be protected from murder.

The corresponding duty that falls on government officials to protect citizens from murder itself yields "waves" of derivative duties to which citizens also have corresponding rights: ${ }^{\mathrm{v}}$ to criminalize murder, thereby declaring to all that such an act is forbidden; to undertake police investigations of all murders in order to determine their perpetrators; to prosecute suspected murderers; to employ the official forum of the conviction process to condemn convicted murderers for their crimes; and to sentence convicted murderers to serious punishments that deter them and others from committing murders in the future. Even the state's activities in resisting unjust aggression in war can be construed, at least partly, as an attempt to protect its citizens from murder. The idea that other activities may be required, as well—such as ransom paymentsmust be taken seriously. The state's duty to protect its citizens from murder is one we take to be among its weightiest. A state that fails in this task is failing a basic sovereign obligation.

It may be replied that a state's obligation to protect its people from murder is location-sensitive. The state is obligated, of course, to protect its 
people from murder when they are located on its own territory. But it is not obligated to protect its people from murder when they are located outside its jurisdiction. This idea has some plausibility. But it is instructive to observe that it is defied by contemporary practice. International law affirms the rights of states to use their power to protect the rights of their people abroad; Article $5^{1}$ of the UN Charter is standardly invoked to justify action taken by states to rescue their unjustly endangered nationals across borders. ${ }^{\mathrm{vi}}$ To be sure, states agree to protect visitors from each other's jurisdictions; the United States can count on Japan to protect Americans in Tokyo from murder. But when a security situation deteriorates, states reserve the prerogative to act, with military power if necessary, to save their people from unjust violence. This is a widely accepted feature of our international practice.

Of course, simply because it ought to be legally permissible for states to protect their citizens abroad from murder does not entail that states are morally required to do so. Some may argue that if a state warns its citizens not to visit a location, precisely due to the dangers involved in such a visit, such citizens cannot reasonably expect to be rescued, especially if the costs of rescue are great. Such citizens have forfeited their claim to be rescued. Let us grant for the sake of argument that this is true for some subset of citizens who visit dangerous places. But it is not obviously true for all citizens who visit dangerous places. Consider the idea that governments have duties to provide foreign aid in dangerous places, and to incentivize others to provide it by, for example, giving tax exempt-status to non-profits who deliver it. Clearly those it sends to discharge these duties, or those it incentivizes to discharge them on 
behalf of those back home, cannot be told that they ought not to have gone. ${ }^{\text {vii }}$ Most democratic governments would not hesitate to dispatch its soldiers to rescue imperiled NGO workers, and at great financial cost. ${ }^{\text {viii }}$ It therefore should not come as a surprise that many governments do not hesitate to pay ransoms to save the lives of their citizens. In the following discussion, accordingly, I shall focus on citizens who have not forfeited their claim to be rescued by ignoring clear warnings.

\section{III}

If the duty to protect citizens from murder is a reason to pay ransoms, the duty to protect citizens from non-lethal harms is a reason not to. The problem we face is this. If we refuse to pay ransoms, fewer persons will be kidnapped, but those who are kidnapped will die. If we pay, many more persons will be kidnapped, but (nearly all of) those who are kidnapped will merely be harmed (e.g., by incurring psychological trauma, deprivation of their liberty of movement, etc.) before they are released. ${ }^{\text {ix }}$ Even if those presently kidnapped will die if we refuse to pay ransom, it is tempting to aggregate the claims of those whose kidnapping is incentivized by such a policy, and so conclude that the costs are greater than the benefits. Call this the incentives objection to paying ransoms.

I will argue that the mere fact that paying ransoms will increase the likelihood of future kidnappings is not sufficient to justify a policy of refusing to pay ransoms. The duty to prevent the moderate non-lethal harms that kidnapped agents experience must not override the duty to prevent murder. 
Even if many people face the prospect of moderate non-lethal harms if we choose one policy, it is not permissible to aggregate those persons' complaints to override a qualitatively more serious prospect of murder faced by others.

T.M. Scanlon familiarly contends that a distinctive appeal of a deontological approach to ethics, properly construed, is precisely that it refuses to permit the kind of aggregation that utilitarianism familiarly enjoins. ${ }^{\mathrm{x}}$ If it did permit it-if an aggregation of moderate complaints could at some point outweigh a single devastating complaint-what is to stop an aggregation of slight, even trivial complaints to outweigh a single devastating complaint? Scanlon famously holds that even if millions of World Cup viewers would be required to pause their enjoyment of the game for fifteen minutes to rescue someone suffering excruciating agony in the television transmitter room, the right course of action is to undertake the rescue. Crank the number of disappointed soccer fans up and up, as high as you like; it won't make a difference. ${ }^{\mathrm{xi}}$

When considering strictly the interests of currently kidnapped and prospectively kidnapped persons, anti-aggregationists, then, should favor the payment of ransoms. That conclusion depends upon a certain plausible assumption: that the non-lethal harms that an agent experiences when kidnapped and subsequently released are categorically less serious than the harms of being kidnapped and killed. This assumption is necessary because, as deontologists tend to agree, aggregation is permissible when the individual claims on each side are comparably serious. For example, if one policy condemns one group to death, and the alternative policy condemns a larger 
group to death, it is right to select the former policy. ${ }^{\text {xii }}$ When the complaints concern disparate levels of seriousness, in contrast, we should not aggregate the weaker complaints to override a stronger complaint. ${ }^{\text {xii }}$ That raises the important question of what renders two harms comparably serious or not. One answer, suggested by Frances Kamm and defended by Alex Voorhoeve, holds that it is impermissible to aggregate harms of type $x$ to outweigh a harm of type $y$ if an agent would have a duty to suffer harm $x$ to rescue another agent from harm $y$. Suppose that we must choose between saving a million people from a brief cold, or saving a person from death. Because an agent would have a duty to suffer a cold to save another from death, it would be wrong to think that an aggregation of such minor harms outweighs even a single death. ${ }^{\text {iv }}$

So the question, then, is whether the non-lethal harms that befall a kidnapped agent (who stands to be rescued) are such an agent would have a duty to suffer them in order to rescue another person from death. If we assume that the answer is 'yes', then aggregation is not permitted, and ransoms should be paid. If we assume that the answer is 'no', then aggregation is permitted, and ransoms should not be paid. So what should we assume?

If kidnappers simply treated hostages exceptionally well, this would make the question of comparable seriousness far easier to determine, strengthening the case for the payment of ransoms. Likewise, the worse that kidnappers treat their hostages—-the more horrifying an incident it is, filled with physical torture and leading to serious post-traumatic anxiety-we may eventually reach a threshold at which the prospect of getting kidnapped and then released may not be much better than getting kidnapped and then killed. 
Strikingly, then, the moral power lies largely with the kidnappers: adopt a practice of treating kidnapped persons like they're luxury hotel guests, and morally-minded governments' calculations will shift accordingly.

Of course, part of the lasting psychological trauma of kidnapping stems from uncertainty about whether a ransom will be paid or not, and thus whether one will die. Muddled messages about whether a government does or does not pay ransoms may have the effect of reducing the likelihood of kidnapping, as compared to a firm public policy of paying ransoms-but they come at a serious cost: radically increasing the harm of the kidnapping itself, even if the hostage is ultimately freed. Locked in a strange place by violent men, waiting to learn whether one is about to be murdered, leaving all of one's family and friends behind forever, is among the most terrifying events that could befall a person. ${ }^{\mathrm{xv}}$ This makes it all the more important for states to settle on an official policy; people are entitled to know what their government will do if they find themselves kidnapped. ${ }^{\text {xvi }}$ If hostages are (mostly ${ }^{\text {xvii }}$ ) confident in the knowledge that they will be rescued, the harm of the experience will decrease considerably.

So it is difficult to issue a blanket judgment on whether "kidnappingfollowed-by-release" is categorically less harmful than "kidnapping-followedby-murder", such that it would be impermissible to aggregate instances of the former to outweigh fewer instances of the latter. Much depends on the circumstances. Suppose we assume that kidnapping-followed-by-release is categorically as serious as kidnapping-followed-by-murder. In that case, the conclusion is clear: we shouldn't pay ransoms, because aggregation is 
permitted. But I doubt that this we are warranted in making this sweeping assumption. If a stable market for kidnapping were up and running, if hostages were fed, housed, and not abused, and if ransoms were predictably paid, it seems plausible that kidnapping-followed-by-release would be categorically less harmful than kidnapping-followed-by-murder; one would not hesitate to choose the former. And so it may be categorically less harmful even in less optimal conditions. So it is certainly plausible that there are circumstances in which aggregation is not permitted, and so the incentives objection to paying ransoms fails. It is for that reason that it is worth inspecting alternative objections that are stronger, which I will do in the next section. Accordingly, for the remainder of the discussion, I will assume that kidnapping-followed-byrelease is categorically less serious than kidnapping-followed-by-murder.

It is important to note that if we could adopt a policy of refusal to pay ransoms (a) without condemning to death anyone presently kidnapped and (b) with the guarantee that such a policy would result in no one being kidnapped in the future, this question would be far easier to answer. But such an assumption would make the problem too easy. The debate on ransoms gets a grip on us precisely because we know that the number of kidnapped persons will not fall to zero, even if a policy of refusal is adopted. Consider, after all, recent kidnappings of American and British citizens, even though both the U.S. and U.K. governments refuse to pay ransom. This empirical fact may be explained in part by the fact that different countries have different policies, and kidnappers may not always be certain of the nationality of those whom they are kidnapping in advance. It may also be explained in part by the fact that some 
wrongdoers may be inclined to try their luck against the odds; even if a ransom is not paid by the country directly, perhaps the country will find an intermediary. In any case, they may still receive valuable publicity for their cause. Thus it is not justified to assume, when offering normative recommendations on this issue, that a policy of refusal to pay ransoms will result in the number of kidnappings dropping to zero. ${ }^{\text {xviii }}$

So far I have considered the matter of whether to pay ransoms solely considering the interests of those who are kidnapped or under some risk of kidnapping. I have done so precisely because this is how the public case against paying ransoms is often framed, as politicians and pundits insist that we owe it to prospectively kidnapped persons not to endanger them by paying ransoms. ${ }^{\text {ix }}$ The argument I have offered so far is that if we take a standard antiaggregationist view in non-consequentialist ethics, and if we accept that being kidnapped and killed is categorically more serious than being kidnapped and released, we ought to favor a policy of paying ransoms. The popular idea that we ought not to pay ransoms because it would be wrong to expose others to increased risks of kidnapping is, I believe, false.

Before proceeding to extend the analysis so that we attend to the indirect effects of ransoms policy, I briefly want to clarify that one need not be an ardent anti-aggregationist to believe that the familiar argument against paying ransoms fails. Scanlon grounds his anti-aggregationism in his own contractualist view, according to which moral principles must be vindicated or rejected solely on the basis of individuals' personal reasons for objecting to or favoring them. ${ }^{x x}$ But we need not embrace this demanding individualist 
restriction in order to embrace the same conclusion: that we ought not to pay ransoms. ${ }^{\mathrm{xxi}}$ Derek Parfit, for example, defends the prioritarian thesis that those who are worse off than others ought to have their claims weighted more heavily in the analysis than those who are better off. ${ }^{x x i}$ He therefore reaches Scanlon's conclusion in cases like the World Cup transmitter room example without endorsing anti-aggregationism.

These two positions will not always converge. Prioritarians will eventually reach a threshold at which devastatingly greater numbers will outweigh the claims of the worse-off (even though those claims have been granted extra weight). No doubt if paying ransoms saved one life, but subjected billions of other lives to the moderate non-lethal harms of kidnapping, prioritarians would conclude that we ought not to pay ransoms. I doubt, empirically, that our present circumstances have this character. If Western governments all begin to pay ransoms, they will rescue the dozens of persons presently kidnapped from death. It is possible that they will then imperil the well-being of hundreds of people who are then kidnapped. Given how much greater a complaint it is to die than to be subjected to non-lethal harm, and given the additional weight such complaints have in virtue of belonging to the worse off, it is at least plausible to suspect that prioritarians should favor the payment of ransoms in our current circumstances.

\section{IV}

When a state focuses on the interests of its citizens alone, there is a plausible case for paying ransoms, at least for those who embrace anti-aggregationism. 
But the interests of threatened co-citizens abroad are manifestly not the only interests at stake in determining whether to pay ransoms. Those who pay ransoms to unjust organizations become reluctant accomplices to those organizations' unjust activities. In recent years, the payment of ransoms has funneled enormous resources into unjust groups. "The source of our financing is the Western countries," declared Oumar Ould Hamaha, a spokesman for an affiliate of Al-Qaeda in the Islamic Maghreb. "They are paying for jihad."xxii This funding has supported Al-Qaeda in a wide range of unjust activities. These include a wide range of activities destabilizing political institutions, or otherwise preventing their development along morally desirable trajectories, in countries including Afghanistan, Algeria, Iraq, Somalia, Syria, Yemen, as well as committing a range of terrorist attacks throughout Europe, Africa, the Middle East, and Asia. ${ }^{x x i v}$ Ransom payments have also formed part of the funding that has enabled ISIS to engage in mass slaughter of civilians in Iraq and Syria. During the year 2016 alone, focusing exclusively on Iraq, the UN's lowest estimate of the number of civilians killed by ISIS was $6,878 .^{\mathrm{xxv}}$

The interests of terrorist groups' victims—-the many who are dead, and the many more suffering from intolerable injustice-surely hang in the moral balance, affecting the permissibility of the choice to pay up. Call this the complicity objection to paying ransoms. The crucial question is this: is the moral reason to protect prospectively kidnapped co-citizens from murder equally strong to our moral reason to refrain from complicity in the murder of others? (Aggregation, recall, is permitted when the individual bads on each side of the moral ledger are comparably serious.) If these reasons our equally strong, 
it seems that the moral arithmetic is straightforward: consider the number of citizens who will die if we refuse to pay ransoms, contrast it to the number of foreigners who will be killed or subjected to qualitatively tantamount bads (e.g., serious injustice), and if the latter is greater than the former, don't pay the ransoms.

Things are not, however, so simple. The problem is that there are different deontically significant ways of being causally implicated in the death of others. Killing is worse than letting die, so we have stronger reason to avoid it. ${ }^{\text {xvi }}$ If we refuse to pay ransoms, we let the hostages die. But if we pay the ransoms, do we kill the innocent Shi'ites, Christians, Yazidis, and rival Sunnis who have been the targets of ISIS's murderous campaign? Of course not: we are not co-principals in their murder. But our actions do make a crucial difference: we have causally contributed to the murders' occurrence. We are complicit. To be sure, those who pay ransoms to rescue their own innocent citizens do not merit the same degree of condemnation as those who pay with the intention of facilitating ISIS's mayhem. But do they impact the wrongness of the acts of complicity itself? ${ }^{x x v i i i}$

Even if we take intention to be relevant to permissibility in some cases, ${ }^{\text {xix }}$ no one believes that good intentions are themselves sufficient to undo the wrongness of seriously harmful acts. That is true even for those who defend the doctrine of double effect. ${ }^{\mathrm{xx}}$ The doctrine of double effect holds that two seemingly identical actions could be differentially permissible depending on the intention of the agent performing the action. But the mere fact that one does not intend to harm innocents - the mere fact that one views the harm as a 
deeply regrettable side-effect of one's intended action-is not sufficient to justify such harm. The good at which one aims must be sufficiently weighty to justify the unintended harm. Of course, if one paid ransoms for the purpose of funding injustice, rather than in order to rescue hostages, it is conceivable that such an evil intention would be enough to render the payment impermissible. Whether that is true just depends on whether one accepts the doctrine of double effect. But such a question does not need to be settled here, because we are assuming, ex hypothesi, that those who pay ransoms react in horror to the prospect that their payments will fund grave rights-violations. My point is simply that this reaction cannot by itself render the payments permissible.

Nor does it matter that ransom payments contribute to murder via the wrongdoing of an intervening agent. Suppose that rather than pay money to terrorists in order to rescue hostages, one instead had to feed cash into a dormant killer robot, which would free the hostages but thereby become activated and proceed to slaughter innocents. Those whose lives are imperiled by the terrorist and the robot have a similar complaint against the payer; what differs is simply that those imperiled by the terrorist also have a complaint against him. Of course, a person's complaint against her murderer is surely greater than her complaint against those who simply aid and abet the murderer. But the mere existence of the former complaint is not enough to make the latter disappear. ${ }^{\mathrm{xxx}}$

Our question, then, is this: is it more wrongful to let a person die by failing to rescue him from harm, or instead to be seriously complicit in a person's murder? It is not at all obvious to me which complaint is weightier. 
They are both seriously pro tanto wrong. It would be difficult to see the argument for why one is categorically worse than the other. For some, the matter may be made somewhat clearer by specifying the nationality of the various parties. Consider which is worse: the complaint of a moral agent against his own government when it fails to rescue him from murder; or the complaint of a moral agent against a foreign government that indispensably aids and abets his murder. This is, roughly, the situation we face when deliberating about whether to pay ransoms to organizations such as ISIS. ${ }^{x x i i}$ Many people are bound to have the intuition that our duties to rescue our fellow citizens are particularly weighty. ${ }^{x x x i i i}$ Relational theorists of global justice, who believe cocitizens have stringent duties to one another, in virtue of the significance of their relationship, are bound to disagree with non-relational cosmopolitans who believe that our moral duties are the same toward co-nationals and foreigners alike. ${ }^{x x x i v}$

Suppose we accept the statist assumption that it is worse for a state to fail to rescue one of its citizens from murder than it is for the state to serve as a causally indispensable facilitator of a foreigner's murder. That may not be true; they may be equally morally bad, or perhaps the latter is, instead, somewhat worse than the former. But even assuming the statist view, it would be difficult to imagine that either is categorically more serious than the other. And if it's true that they are in the same league, morally speaking, then one important implication follows: aggregation is permitted.

That result, if correct, makes the right thing to do a matter of numbers. If it turns out that a policy of paying ransoms saves significantly more persons 
from death than it condemns to death, than it is the morally required path. Ifas I suspect applies to democratic nations' present predicament-the matter works the other way around, things look different. Paying ransoms may well cause more death than it prevents, and so even deontologists should, it now seems, refuse to pay.

My best judgment, then, in response to the question that has rattled the public over the past several years, is that we ought not to pay ransoms to terrorist organizations. Because this is my judgment, I set aside other fascinating but difficult questions that one would need to answer if one wished to endorse a policy of paying ransoms (e.g., concerning the appropriate amount of resources spent on ransom payments, and how to think about the relationship between resources spent on paying ransoms and other life-saving programs, like policing and healthcare, in a nation's budget). Still, I want to close this section by briefly sketching an alternative policy in this area.

So far we have so far supposed that the state faces the following dichotomous choice: pay ransoms, or don't pay ransoms. There is, among others, a third option: pay the ransoms, and then take action to prevent or mitigate the pernicious consequences of so doing. Specifically, if paying ransoms confers resources on wrongdoers that enable them to initiate causal chains culminating in further grievous wrongdoing, the right response to this fact is not to refuse to pay ransoms, but rather to pay the ransoms-thereby saving lives-and then to take further measures to disrupt those very causal chains. For example, the government can attempt to reclaim the resources they have paid out by tracking and then intercepting them. 
If it is possible to pay ransoms and then swiftly intercept the funds, states ought to do so. When reclaiming the funds themselves is not feasible, a state that pays ransoms to unjust organizations could instead offset the financial effects of payment, by, for example, destroying terrorists' assets and depleting their capital base. ${ }^{\mathrm{xxxv}}$ Targeted air strikes on oil facilities controlled by ISIS, on ammunitions facilities, and on infrastructure all constitute ways for a state to make sure that it has not left the unjust organization materially better off by paying the ransom. So, too, do investments in, for example, the Iraqi government, which help it more effectively regain control of territory seized by ISIS. ${ }^{x x x v i}$

Unlike operations to reclaim the specific funds one has just paid, offsetting the bad effects of one's ransom payment may not be sufficient to render such payment permissible. ${ }^{\text {xxxvii }}$ Non-consequentialists do not believe that it is acceptable to aid and abet the murder of some people today, just so long as we promise to save some number of lives in the future. For offsetting to render ransom payment permissible, it must happen reasonably quickly after the ransom has been paid, before the money has been used to fund serious injustice. Still, what seems clear is that even when offsetting is not enough to make payment acceptable-say, because it happens too late-it is better than nothing. If a nation insists on paying ransoms, it should at least take measures to offset the bad effects of doing so. ${ }^{\text {xxxviii }}$ 
In this last section I want to trace the implications of the analysis above for two normative questions: on paying ransoms to groups with innocuous or even morally laudable aims; and on the permissibility of paying ransoms from private bank accounts, such as those of hostages' family members, rather than from public funds.

First, recall that the impermissibility of paying ransoms depends in part on the evil that ransom payments fund. But what if paying the ransom does little evil? Set aside the question of whether kidnapping could ever be morally justified in the service of one's just end. For that to be so, barring exceptional circumstances, the hostage and the party from which the ransom is demanded would need to be morally liable to suffer these costs (e.g., if they were culpably responsible for whatever injustice the ransom will be used to eliminate, and if subjecting them to this treatment was a necessary and proportionate means of enforcing their duty to eliminate the injustice). ${ }^{x x x i x}$ I assume that even if one has a just cause, kidnapping and demanding ransom under threat of death is a morally impermissible mode of pursuing that cause. Even so, might the fact that the cause is just affect the permissibility of the decision pay ransom itself? I believe the answer is unavoidably 'yes'.

If the best objection to paying ransoms is the causal contribution the ransom payments make to serious injustice, as I have argued, this objection attenuates in force as the injustice of the kidnappers' cause diminishes. If the kidnappers are simply using the ransom payments to buy themselves luxurious holiday homes, then while no doubt their conduct remains seriously objectionable, and they ought to be hunted down and brought to justice for 
their crimes, we do not causally contribute to significant evil by paying ransoms. That is true, a fortiori, if their use of the ransom money is not merely morally innocuous, but morally just. ${ }^{\mathrm{xl}}$ This fact would not, I stress, render kidnapping permissible. But it would alter the objection to paying the ransom. Thus one conclusion to draw from the analysis here is that the fact that it is wrong to pay ransoms to unjust terrorist organizations does not imply that it is wrong to pay ransoms simpliciter. If the money is not going to fund evil, then the weighty claim of a citizen to be rescued from murder stands. The case against paying ransoms in such cases is considerably weaker. ${ }^{\text {xli }}$

Of course, the standard cases on which this essay has concentrated are those in which an unjust organization holds hostages in order to secure funding for an unjust cause. One last question remains about these cases. Even if we decide that governments ought not to pay ransoms, it is a further question whether it is objectionable for private citizens to pay for ransoms-be it the kidnapped person himself, through his own funds or by kidnapping insurance, or the kidnapped persons' associates, such as employers, friends, and relatives. Perhaps the government should refrain from paying ransoms, but leave citizens free to pay if they can afford it; Barack Obama himself seems to have held such a view. ${ }^{x l i i}$ I do not develop a full argument on this matter here, since our focus has been constrained to the question of government policy. But I will close by offering the rudiments of a plausible position.

One worry about permitting private ransom payments is that, in an inegalitarian world, wealthy journalists and aid workers, or those who happen to work for large corporations, would be freed, whereas others who were 
kidnapped would die. ${ }^{\text {xliii }}$ If the government steps up to offer financial assistance to poorer hostages, it will counterproductively undermine its own policy of refusing to pay ransoms; if it bans private payments for this reason, it engages in a perversely lethal form of levelling down. But there is a deeper objection at work when considering whether to pay ransoms to unjust terrorist organizations. The duty not to fund injustice is a duty that bears on all agents, not simply governments. Suppose my wife is kidnapped by ISIS, and I can afford to pay the ransom. By paying it, however, I pay for the weapons that enable the extermination of many Yazidis in Iraq. Even if we assume that there are cases in which I would be permitted to pay the ransom—-because my special positive duty to rescue my wife is more stringent than my general negative duty to refrain from making a causal contribution to the murder of strangers-this will be so only when a small number of strangers' lives hang in the balance. Consider: even if we think that I am permitted to rescue my spouse when she is drowning, as opposed to rescuing 2 strangers, there is likely some number of strangers for which no plausible view will continue to grant me that permission (even if we would hesitate to blame me). xliv The same applies in the case of ransoms.

Note that it applies even if the ransom demand takes a non-monetary form. If I am a scientist with a formula for the perfect chemical weapon, and I can save my wife's life only by handing it over to madmen, I must let my wife die. And if it is my own life that hangs in the balance, the result is the same; an agent-relative prerogative may permit me to save my own life instead of another innocent person's life-possibly even several people's lives-but if we 
raise the stakes sufficiently, such that dozens or hundreds or thousands of lives hang in the balance, that prerogative will eventually disappear. ${ }^{\mathrm{xlv}}$

The question of whether to pay ransoms to terrorist organizations, in sum, is complicated. No wonder, then, that the public debate continues to face an impasse, with democratic governments divided starkly on whether to pay up to free hostages. But if the analysis here is right, we have good reason to presume that paying ransoms to those who unstoppably spend that money on grave evil is not morally justified.

Jeffrey W. Howard, Lecturer in Political Theory, Department of Political Science, University College London, 29-31 Tavistock Square, London WC1H 9QU, UK. jeffrey.howard@ucl.ac.uk

\section{Acknowledgments}

I am grateful to an audience at the American Philosophical Association Eastern Division Conference, and especially to my respondent Dale Miller and copanelist George R. Lucas, for extremely useful feedback on an early version of this paper. I am also grateful to audiences at the University of Essex. Finally, I would like to thank Paul Bou-Habib, Thomas Gift, Bob Goodin, Emily McTernan, Jonathan Monten, and Tom Parr for helpful discussion.

\footnotetext{
${ }^{\mathrm{i}}$ For discussion of this issue in the case of economic piracy, see James Pattinson, "Justa Piratica: The Ethics of Piracy," Review of International Studies 40, 4 (2014): 631-56. Here I restrict the discussion to cases of impermissible kidnapping.

ii Rukmini Callimachi, "Paying Ransoms, Europe Bankrolls Qaeda Terror," The New York Times, July 29, 2014.

iii Leviathan, ed. C.B. Macpherson (London: Penguin Books 1968 [1651]), p. 272.

${ }^{\text {iv }}$ For example, as a special assignment belonging to an international division of moral labor; see Robert Goodin, “What's So Special about Our Fellow Countrymen?” Ethics 98, 4 (1988): 663686. Alternatively, they might be traceable to special associative duties that members of a shared political order have toward one another. Such special duties might be grounded in
} 
citizens' shared cooperation in a social scheme that generates the primary social goods necessary for living an autonomous life, as suggested by John Rawls, A Theory of Justice (Cambridge, MA: Harvard University Press) and explicitly defended by Andrea Sangiovanni, "Global Justice, Reciprocity, and the State," Philosophy \& Public Affairs 35, 1 (2007): 3-39. Alternatively, they might be grounded in the normative significance of shared national identity; see David Miller, On Nationality (Oxford: Oxford University Press, 1995).

v For the idea of "waves of duties," see Jeremy Waldron, "Rights in Conflict," Ethics 99, 3 (1989): 503-19, pp. 509ff.

${ }^{\text {vi }}$ See Rez Zedalis, "Protection of Nationals Abroad: Is Consent the Basis of Legal Obligation?" Texas International Law Journal 25 (1990): 209-270; Andrew W.R. Thomson, "Doctrine of the Protection of Nationals Abroad: Rise of the Non-Combatant Evacuation Operation," Washington University Global Studies Law Review 11, 3 (2012): 627-668.

vii A similar idea could well apply to journalists: if we have obligations to find out what is happening in dangerous places abroad (so that we can be informed about how best to discharge our moral duties to assist), journalists enable us to discharge precisely these duties. It may not be plausible to say these journalists ought not to have gone.

viii This leaves open the possibility that these jobs, like the jobs of soldiers, should simply be significantly better paid in virtue of the dangers they involve. Of course, it is telling that militaries standardly pay ransoms-usually in the form of prisoner-swaps-to rescue their captured soldiers.

ix There is strong incentive for kidnappers to release hostages once ransoms are paid; otherwise the business model fails to work. See Anja Shortland, "Governing Kidnap for Ransom: Lloyd's as a 'Private Regime'," Governance (online early view: DOI: 10.1111/gove.12255), 2016. I address complications below.

${ }^{x}$ Scanlon, What We Owe to Each Other, p. 241.

xi Ibid., p. 235.

xii Scanlon, What We Owe to Each Other, p. 232; F.M. Kamm, Morality, Mortality, volume 1 (Oxford: Oxford University Press, 1993), pp. 116-17.

xiii For the significance of categories of moral seriousness, see Scanlon, What We Owe to Each Other, p. 238.

xiv Frances Kamm, Bioethical Prescriptions (Oxford: Oxford University Press, 2014), p. 369; Alex Voorhoeve, "How Should We Aggregate Competing Claims?" Ethics 125, 1 (2014): 64-87. Those who reject this account will clearly arrive at a different view about when aggregation is permitted. See, for example, John Halstead, "The Numbers Always Count," Ethics 126, 3 (2016): 789-802. It would be fruitful to trace out the implications of different views on aggregation for this debate; unfortunately tracing out all such views here would take me too far afield, so I focus on the simple anti-aggregationism defended by Scanlon as an illustrative example. My topic is ransoms, not aggregation.

${ }^{x v}$ For scholarly discussion, see David A. Alexander and Susan Klein, "Kidnapping and HostageTaking: A Review of Effects, Coping, and Resilience," Journal of the Royal Society of Medicine 102, 1 (2009): 16-21. For gripping descriptions of this experience, consult the autobiography of Captain Richard Phillips (the subject of an eponymous film starring Tom Hanks), A Captain's Duty: Somali Pirates, Navy SEALS, and Dangerous Days at Sea (New York: Hachette Books, 2010).

xvi I thank an anonymous reviewer for drawing this point to my attention.

xvii For further discussion of the ways in which clear policies help the stabilize the market in ransom payments, see Shortland, "Governing Kidnap for Ransom." See the next note for further discussion.

xviii Likewise, while it is helpful to assume, as I have, that those kidnapped under a regime of paying ransoms will all be rescued, this is merely a simplifying assumption. It may be that in some cases, due to failure to agree on a price, some hostages will be killed even in a regime in which there is a standing policy of paying ransoms. The question, then, is whether the number of people killed under such a regime-in which ransoms are paid but some hostages are killed anyway-is higher than the number of people killed under a regime of absolute refusal to pay 
ransoms. I shall assume that under a stable regime of paying ransoms, the former number is lower.

xix Consider Canadian Prime Minister Justin Trudeau's reaction as a representative example, as reported in Ashifa Kassam, "Should governments pay ransoms? For families of hostages, it's complicated," The Guardian, Friday, June 17, 2016.

${ }^{x x}$ For an explication and defense of his view, see Michael Ridge, "Saving Scanlon: Contractualism and Agent-Relativity," The Journal of Political Philosophy 9, 4 (2001): 472-481.

${ }^{x x i}$ For criticism of the individualist restriction, see Derek Parfit, On What Matters, volume 2 (Oxford: Oxford University Press, 2011), pp. 191-212, and Michael Otsuka, "Saving Lives, Moral Theory, and the Claims of Individuals," Philosophy \& Public Affairs 34, 2 (2006): 109-35. See also Sophia Reibetanz, "Contractualism and Aggregation," Ethics 108, 2 (1998): 296-311, and Joseph Raz, "Numbers, with and without Contractualism," Ratio 16, 4 (2003): 346-67.

xxii For discussion of this idea in relation to Scanlon, see Parfit, On What Matters, volume 2, p. 198.

xxiii Adam Nossiter, "Millions in Ransoms Fuel Militants' Clout in North Africa," The New York Times, December 12, 2012.

xxiv Al-Qaeda and its affiliates have raised \$125 million in revenue from ransoms payments since 2008 - \$66 million of which was paid during the past year. See Rukmini Callimachi, "Paying Ransoms, Europe Bankrolls Qaeda Terror," The New York Times, July 29, 2014. Ransoms have also become a lucrative source of revenue for ISIS. ISIS has made approximately \$20 million from kidnapping ransoms during the year 2014. Brett Logiurato, "ISIS Is Making An Absurd Amount Of Money On Ransom Payments And Black-Market Oil Sales," Business Insider, 23 October 2014. With this money it has conquered a significant portion of territory; at one point roughly $35 \%$ of Syria was in ISIS control, as well as a significant portion of Iraq to Baghdad's west. The devastation it has unleashed is undeniable. Between January and July 2014 alone, more than 5,500 civilians were killed because of ISIS-related violence, and 11, 665 wounded. Associated Press, "Iraqi civilian death toll passes 5,50o in wake if Isis offensive," The Guardian, July 18, 2014.

xxv Bethan McKernan, "Scale of Iraqi civilian casualties inflicted by Isis revealed by UN," The Independent, January 3, 2017.

xxvi Judith Jarvis Thomson, "Killing, Letting Die and the Trolley Problem," in W. Parent (ed.), Rights, Restitution, and Risk: Essays in Moral Theory (Cambridge: Harvard University Press, 1986). For the classic criticism, see James Rachels, "Active and Passive Euthanasia," New England Journal of Medicine 292 (1975): 78-86. See also Jeff McMahan, "Killing, Letting Die, and Withdrawing Aid," Ethics 103 (1993): 250-279;

xxvii Here I follow the idea that, to be complicit in wrongdoing, one must have actually made a causal difference; Chiara Lepora and Robert E. Goodin, On Complicity and Compromise (Oxford: Oxford University Press, 2013), and John Gardner, "Complicity and Causality," in Offences and Defences: Selected Essays in the Philosophy of Criminal Law (Oxford: Oxford University Press, 2007). Cf. Christopher Kutz, Complicity: Ethics and Law for a Collective Age (Cambridge: Cambridge University Press, 2007). It is, in fact, doubtful whether Kutz's analysis, which focuses on intentionality rather than causal difference-making, is an analysis of complicity at all, rather than co-principalship; see John Gardner, "Review: Christopher Kutz, Complicity: Ethics and Law for a Collective Age," Ethics 114, 4 (2004): 827-30.

xxviii Lepora and Goodin argue that these factors are only relevant to blameworthiness.

${ }^{x x i x}$ For discussion on this issue, see T.M. Scanlon, Moral Dimensions (Cambridge, MA: Harvard University Press, 2008), pp. 37ff; Frances Kamm, Intricate Ethics (Oxford: Oxford University Press, 2007), Chapter 5; Judith Jarvis Thomson, "Physician-Assisted Suicide: Two Moral Arguments," Ethics 109, 3 (1999): 497-518. Cf. Victor Tadros, The Ends of Harm: The Moral Foundations of Criminal Law (Oxford: Oxford University Press, 2011), pp. 139-66.

${ }^{x x x}$ The doctrine of double effect is an application of the idea that the same action can be permissible or impermissible depending on the intention of the agent. Following Jeff McMahan, "The key element in the Doctrine of Double Effect (DDE) is the claim that there is a stronger presumption against action that has harm to the innocent as an intended effect than there is against otherwise comparable action that causes the same amount of harm to the innocent as a 
foreseen but unintended effect." McMahan, "Revising the Doctrine of Double Effect," Journal of Applied Philosophy 11, 2 (1994): 201-212, p. 211. For a rejection of the doctrine of double effect, see Scanlon, Moral Dimensions, Chapter 1. My argument here does not depend on whether the double of double effect is true, for even if it is true-even if one's intention matters-the good that one intends to bring about through one's action must be sufficiently great to justify the unintended harm caused as a side-effect.

xxi Here I broadly follow the instructive discussion of intervening agency in Victor Tadros, "Permissibility in a World of Wrongdoing," Philosophy \& Public Affairs 44, 2 (2016): 101-132, pp. 122-128.

xxxii Of course, in some cases, the people who will be killed by terrorists will be one's own fellow citizens, killed in terrorist attacks in one's home country. This fact simplifies matters somewhat. The question here is whether it is worse to fail to rescue one's fellow citizen from murder, or aid and abet the murder of one's fellow citizen.

xxxiii For a defense of this claim, see Seth Lazar, "Associative Duties and the Ethics of Killing in War," Journal of Practical Ethics (online only) 2014; available at http://www.jpe.ox.ac.uk/papers/associative-duties-and-the-ethics-of-killing-in-war.

xxxiv One could easily imagine, for example, liberal nationalists-who believe the shared national culture of citizens grounds special responsibilities toward one another-arguing that the special, positive duty to rescue one's fellow nationals from murder is sufficiently stringent to outweigh the general, negative duty not to be complicit in murder. Likewise, one could easily imagine relational theorists who believe that the relationship of co-citizens is special in various ways related to questions of distributive equality, but insist that such fundamental principles of rescue, killing, and letting die do not admit of varying stringency on the basis of nationality. And one could certainly imagine cosmopolitans insisting that our relationships to co-nationals are simply instrumentally valuable, if at all. Obviously writers on global justice have not addressed the matter of paying ransoms.

${ }^{x x x v}$ See Barbara Starr, "U.S. Bombs 'Millions' in ISIS Currency Holdings," CNN Politics, January 13, 2016, available at http://edition.cnn.com/2016/o1/11/politics/us-bombs-millions-isis-

currency-supply; and David Stupples, "How to Defeat ISIS By Cutting Off Its Funds," Newsweek, December 6, 2015, available at http://www.newsweek.com/how-defeat-isis-cutting-their-funds401281

xxxvi Of course, states may already have duties to engage in humanitarian assistance and intervention that may enjoin similar courses of action. Those who pay ransoms have amplified versions of these duties.

xxxvii I am grateful to an anonymous reviewer for pressing me on this point.

xxxviii This is not the only creative alternative to the familiar dichotomy of "pay or don't pay." One possibility involves offering criminal immunity, plus a large financial reward, to anyoneincluding a member of a terrorist organization-willing to defect and disclose information leading to a successful military operation to rescue kidnapped hostages. For this argument, see David McAdams, "The Right Way to Pay Ransoms to Terrorists," The New York Times, February 3, 2015. (Note that this is also the plot for the 1996 blockbuster "Ransom," directed by Ron Howard.)

xxxix For further discussion on the permissibility of kidnapping in the case of piracy, see James Pattinson, "Justa Piratica: The Ethics of Piracy."

${ }^{x l}$ For example, in the 1996 blockbuster film "The Rock," directed by Michael Bay, a vigilante general unjustifiably holds a group of tourists hostage and threatens to kill them (alongside the entire population of San Francisco) unless the U.S. government pays a ransom, which will be mostly used to pay compensation to veterans' families to which those families are morally entitled. Clearly the government should pay up in such a case.

xli This does not lead straightforwardly to the conclusion that a ransom should be paid, whatever the price. As I specified earlier, it remains an open question what the appropriate price for the ransom payment is.

xlii Dan Roberts, "Obama administration clears way for hostages' families to pay ransoms," The Guardian, June 24, 2015.

xliii Admittedly they might be more likely to be targeted by kidnappers. 
xliv See Lazar, "Associative Duties and the Ethics of Killing in War," for various examples of cases in which one must choose between rescuing close associates and strangers.

xlv For related discussion, see Jonathan Quong, "Agent-Relative Prerogatives to Do Harm," Criminal Law \& Philosophy 10, 4 (2016): 815-829. 